\title{
小児集中治療室での鎮痛・鎮静管理：看護師による現状調 查
}

\author{
辻尾有利子*1 志馬 伸朗 $* 2,3$ 德平 夏子*2 大澤 智美*1
}

\begin{abstract}
要約：【目的】日本の小児集中治療室 (PICU) の鎮痛・鎮静管理の実践現状を看護師の視点から 明らかにする。【方法】看護単位が独立した 25 施設のPICUの看護師を対象に，施設の実践現 状に対する質問紙調査を行った。【結果】17施設より回答を得た。鎮痛・鎮静に関して, 客観 的評価を行っている施設はそれぞれ $41.2 \% \cdot 23.5 \%$ ，目標深度を設定している施設は $23.5 \%$ ・ $41.2 \%$ ，マニュアルがある施設は $11.8 \%$ ・ $5.9 \%$ ，看護師主導の管理を行っている施設は $29.4 \% \cdot 17.6 \%$ でった。薬物療法では, ミダゾラム, フェンタニル，デクスメデトミジンの 持続投与が多かった。多くの施設が離脱症状の問題について認識し, 積極的に非薬物療法に 取り組んでいたが, 鎮痛・鎮静管理に満足と回答した割合は $29.4 \% \cdot 47.1 \%$ と低かった。【結語】 PICUの看護師にとって鎮痛・鎮静管理の現状は，満足すべき状況ではないと考えられた。
\end{abstract}

Key words: (1) PICU, (2) analgesia, (3) sedation

\section{はじめに}

小児集中治療室 (PICU) 患者の身体的・精神的苦 痛を減らし，早期回復を促すために，適切な鎮痛・ 鎮静管理が重要である11。日本のPICUでの鎮痛・鎮 静管理を看護師がいかに認識, 実践, 評価しているか 調査した。

\section{対象と方法}

2012年 2 ～月に, 全国の看護単位が独立したPICU 25 施設の看護師長に調查協力を依頼し, 質問紙を送付 した。調查の内容は, 理想とする鎮痛・鎮静管理, 鎮 痛・鎮静の評価法, 現在の鎮痛・鎮静管理法, 離脱症 状に対する認識と現状, 薬物療法 (短期挿管中, 長期 挿管中, 非侵襲的陽圧換気中, 非挿管中, 処置時), 非 薬物療法の現状である。なお, 調查は, 施設の見解を

この論文は今号のハイライトで取り上げています。 竹内宗之, 小山 英彦, 橘一也. わが国のPICUに おける鎮痛・鎮静 〜満足できる鎮痛・鎮静レベルを得るた めに〜。 日集中医誌 2015;22:245-6.
回答できると考えられる看護師長または看護主任, 5 年以上のPICU 経験を有する看護師が, 集中治療医の 協力のもと回答するように依頼した。研究参加は自由 意思に基づき, 質問紙の返送をもって研究参加の同意 とした。

本研究は, 京都府立医科大学倫理審査委員会におい て承認を得た。

\section{結 果}

17 施設より回答を得た（回答率 $68.0 \%)$ 。回答を得 た 17 施設は, いずれも内科系・外科系の重症患者, 院 内外の急変患者を対象とし, うち 4 施設は三次救急患 者も対象としていた。

\section{1) 満足度と阻害因子 (自由記載)}

現在の鎮痛・鎮静管理に満足しているのはそれぞれ $5(29.4 \%) \cdot 8(47.1 \%)$ 施設であった。阻害因子は, 疾 患や診療科による薬剤や目標の相違, 社会的事情によ る深鎮静, 鎮痛の認識不足, 乳幼児の評価困難, 鎮痛· 鎮静の区別困難, 客観的指標やマニュアルがない, 筋 弛緩薬の投与, 循環変動, 医師と看護師の認識の相違,

\footnotetext{
*1 京都府立医科大学附属病院看護部, $* 2$ 同 集中治療部

（ ₹ 602-8566 京都府京都市上京区河原町通広小路上儿梶井町 465）

*3 国立病院機構京都医療センター救命救急科 (

受付日 2012 年 11 月 6 日 採択日 2014 年 10 月 14 日
} 
Table 1 Frequently used sedative and analgesic drugs in several ventilatory status in PICUs in Japan

\begin{tabular}{|c|c|c|}
\hline Purpose & Drugs & $\mathrm{n}(\%)$ \\
\hline \multirow[t]{6}{*}{ Invasive ventilation (short-term) } & Midazolam & $17(100)$ \\
\hline & Fentanyl & $13(76.5)$ \\
\hline & Dexmedetomidine & $12(70.6)$ \\
\hline & Enteral triclofos & $6(35.3)$ \\
\hline & Morphine & $4(23.5)$ \\
\hline & Chlorpromazine & $4(23.5)$ \\
\hline \multirow[t]{5}{*}{ Invasive ventilation (long-term) } & Midazolam & $17(100)$ \\
\hline & Fentanyl & $15(88.2)$ \\
\hline & Dexmedetomidine & $11(64.7)$ \\
\hline & Morphine & $5(29.4)$ \\
\hline & Phenobarbital & $4(23.5)$ \\
\hline \multirow[t]{6}{*}{ Noninvasive ventilation } & Dexmedetomidine & $10(58.8)$ \\
\hline & Midazolam & $8(47.1)$ \\
\hline & Enteral triclofos & $8(47.1)$ \\
\hline & Chloral hydrate suppository & $4(23.5)$ \\
\hline & Phenobarbital & $4(23.5)$ \\
\hline & Fentanyl & $2(11.8)$ \\
\hline \multirow[t]{6}{*}{ Without mechanical ventilation } & Enteral triclofos & $13(76.5)$ \\
\hline & Dexmedetomidine & $11(64.7)$ \\
\hline & Chloral hydrate suppository & $9(52.9)$ \\
\hline & Fentanyl & $6(35.3)$ \\
\hline & Midazolam & $4(23.5)$ \\
\hline & Acetaminophen, NSAIDs & $4(23.5)$ \\
\hline \multirow[t]{5}{*}{ Procedural } & Midazolam & $13(76.5)$ \\
\hline & Ketamine & $7(41.2)$ \\
\hline & Fentanyl & $7(41.2)$ \\
\hline & Propofol & $4(23.5)$ \\
\hline & Lidocaine & $4(23.5)$ \\
\hline
\end{tabular}

Numbers and percentages of the institutes of using the drugs are presented. NSAIDs, nonsteroidal anti-inflammatory drugs.

成長発達段階別の対応，などであった。

\section{2) 評価法 (複数回答)}

全施設が“客観的な経時的評価が必要”と答えた。 鎮痛の客観的評価は7施設 (Face Scale 4施設, visual analog scale 2施設, Children's Hospital of Eastern Ontario Pain Scale ${ }^{2)}$ 1施設), 主観的評価10施設, 評 価なし5施設であった。

鎮静の客観的評価は4施設 (State Behavioral Scale 1施設, Ramsay scale 1施設, Richmond AgitationSedation Scale 1施設, Sedation-Agitation Scale 1施 設, 独自スケール4施設)，主観的評価8施設，評価な し4施設であった。

鎮痛・鎮静の経時的評価は $5(29.4 \%) \cdot 10(58.8 \%)$
施設で行われていた。

\section{3）目標設定と管理法}

目標鎮痛・鎮静深度の設定は, $15(88.2 \%) ・ 17$ (100\%) 施設が “必要”と回答し, 実際に設定している のは4 $(23.5 \%) \cdot 7(41.2 \%)$ 施設であった。

鎮痛・鎮静マニュアルは16 (94.1\%)・17 (100\%) 施 設が “必要”と回答し，実在するのは $2(11.8 \%) ・ 1$ (5.9\%) 施設であった。看護師主導の管理は5 $(29.4 \%) \cdot 3(17.6 \%)$ 施設, 毎日の鎮静の中断 (減量) は2 $2(11.8 \%)$ 施設で行われていた。

\section{4) 離脱症状}

全施設が離脱症状の出現を経験していた。13施設 (76.5\%) が対策を講じ, 1施設 (5.9\%) がWithdrawal 
Assessment Tool-1 (WAT-1) 3)を用いていた。

5) 薬物

ミダゾラム, フェンタニル, デクスメデトミジンが 多かった $($ Table 1)。鎮痛主体の管理は6 (35.3\%) 施 設で行われていた。

\section{6) 非薬物療法 (自由記載)}

面会制限の緩和, 全人的苦痛の緩和, 心理的準備, 安楽な体位, 温冷罨法, あやし(機嫌を取ってなだめ る), 注意転換, 環境調整, 早期退室, などが行われて いた。

\section{考 察}

看護師からみたPICUでの鎮痛・鎮静管理は, 評価 法やマニュアルの整備が必要であると認識されている が, 実践はこれと乘離しており, 看護師が満足すべき 状況にないと考えられた。

客観的鎮痛・鎮静評価の必要性は認識されている が，実践施設は7施設 (41.2\%)，4施設 (23.5\%)で，海 外報告 $\left(37.5 \%{ }^{4)}, 40 \%{ }^{5)}\right)$ と同様に少ない。また, 目 標深度の設定や, 鎮痛・鎮静管理プロトコルの必要性 も認識されているが, 実践施設は少ない。これらの理 想と実践の乘離は, 単一の指標を用いて全小児を評価 する困難性 6), 鎮痛と鎮静を区別することの困難性 7), 困難と認識している内容 (阻害因子) などから, 小児特 有の問題が関連していると考えられた。

多くの施設が, 離脱症状を重要と認識し, 予防と管 理に努めていたが, 客観的評価法の使用は 1 施設のみ であり, 普及を考慮する余地がある。また, 看護師主 導の管理により, 薬物投与量が減少 ${ }^{8)}$, 苦痛緩和への 介入の迅速化 ${ }^{9)}$ が報告されている。非薬物療法は, 英 国ガイドラインConsensus guidelines on sedation

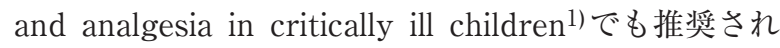
ており, 小児の状況に合わせた細やかな看護ケアは鎮 痛・鎮静薬の投与量の減少にもつながりうるため, 今 後検討する余地がある。

\section{結 論}

PICUの看護師にとって鎮痛・鎮静管理の現状は満 足すべき状況ではないと考えられた。

\section{謝 辞}

本調查に御協力頂いた施設の皆様に厚く御礼申し上げま す。

本稿の全ての著者には規定されたCOIはない。

\section{文 献}

1) Playfor S, Jenkins I, Boyles C, et al; United Kingdom Paediatric Intensive Care Society Sedation; Analgesia and Neuromuscular Blockade Working Group. Consensus guidelines on sedation and analgesia in critically ill children. Intensive Care Med 2006;32:1125-36.

2) von Baeyer CL, Spagrud LJ. Systematic review of observational (behavioral) measures of pain for children and adolescents aged 3 to 18 years. Pain 2007;127:140-50.

3) Franck L, Harris S, Soetenga DJ, et al. The Withdrawal Assessment Tool-1 (WAT-1): an assessment instrument for monitoring opioid and benzodiazepine withdrawal symptoms in pediatric patients. Pediatr Crit Care Med 2008;9:573-80.

4) Long D, Horn D, Keogh S. A survey of sedation assessment and management in Australian and New Zealand paediatric intensive care patients requiring prolonged mechanical ventilation. Aust Crit Care 2005;18:152-7.

5) Jenkins IA, Playfor SD, Bevan C, et al. Current United Kingdom sedation practice in pediatric intensive care. Paediatr Anaesth 2007;17:675-83.

6) Razmus I, Wilson D. Current trends in the development of sedation/analgesia scales for the pediatric critical care patient. Pediatr Nurs 2006;32:435-41.

7) Ramelet AS. Assessment of pain and agitation in critically ill infants. Aust Crit Care 1999;12:92-6.

8) Deeter KH, King MA, Ridling D, et al. Successful implementation of a pediatric sedation protocol for mechanically ventilated patients. Crit Care Med 2011;39:683-8.

9) Alexander E, Carnevale FA, Razack S. Evaluation of a sedation protocol for intubated critically ill children. Intensive Crit Care Nurs 2002;18:292-301. 


\title{
Abstract
}

Analgesia and sedation in Japanese pediatric intensive care unit: a survey study by nurses

\author{
Yuriko Tsujio*1, Nobuaki Shime*2,3, Natsuko Tokuhira*2, Satomi Osawa*1 \\ ${ }^{* 1}$ Department of Nursing, *2 Anesthesiology and Intensive Care, University Hospital, Kyoto Prefectural University of Medicine \\ ${ }^{*}$ Department of Emergency and Critical Care Medicine, National Hospital Organization Kyoto Medical Center \\ *1, 2465 Kajii-cho, Kawaramachi-Hirokoji, Kamigyo-ku, Kyoto, Kyoto 602-8566, Japan \\ ${ }^{* 3}$ 1-1 Mukaihata-cho, Fukakusa, Fushimi-ku, Kyoto, Kyoto 612-8555, Japan
}

Objectives: To evaluate current status and problems for the management of analgesia and sedation in Japanese PICU by nurses' viewpoint. Method: A questionnaire concerning analgesia and sedation strategies was sent to all 25 PICUs in Japan. Results: Responses were obtained from 17 units. Among them, $41.2 \%$ of the facilities use objective evaluation scoring for pain and $23.5 \%$ for sedation, while $23.5 \%$ of the facilities set the ideal level of pain relief and $41.2 \%$ do so for sedation. In addition, $11.8 \%$ follow a protocol for pain relief and $5.9 \%$ for sedation. In $29.4 \%$ of the facilities, nurses control pain and in $17.6 \%$, they control sedation. The commonly used sedatives and analgesics were midazolam, fentanyl and dexmedetomidine. Most of the units recognized withdrawal syndrome, and tried non-pharmacological interventions. Only $29.4 \%$ of nurses were satisfied with the existing pain management practices and $47.1 \%$ were satisfied with sedation practices. Conclusion: According to Japanese PICU nurses, the current management strategies for analgesia and sedation are not yet satisfactory.

Key words: (1) PICU, (2) analgesia, (3) sedation 